\title{
МИСТЕЦТВОЗНАВСТВО
}

DOI: https://doi.org/10.32839/2304-5809/2020-12-88-18

УДК 393.3(477)

Климчук I.C. ${ }^{1}$

Національна академія керівних кадрів культури і мистецтв

\section{УКРАЇНСЬКА НАЦІОНАЛЬНА БАЛЕТНА ВИСТАВА В УРСР В ОПТИЦІ СОЦРЕАЛІЗМУ}

Анотація. У статті проаналізовано етапи становлення української націо-нальної балетної вистави крізь призму соцреалістичного канону. Зазначено, що естетика соцреалізму як легітимізований владою регулятор мистецьких процесів проявився в одній з найпотужніших тенденцій 30-80-х pp. XX ст. - створенні національних балетних вистав в союзних республіках. Попри ідеологічні настанови, створення українських балетів позитивно позначилося на загальному розвитку балетного театру України, розширило його жанровий діапазон, сприяло підвищенню професійного рівня митців, органічне поєднання класичного та українського танцю призвело до появи унікальної лексичної системи національної балетної вистави. Українська національна балетна вистава пройшла шлях від побутової драми «Пан Каньовський» (перший український балет) через «Лілею» (перша українська хореодрама) до симфонічної поеми «Лісова пісня», що відбиває основні віхи розвитку балетного театру УРСР у 30-50-х pp.

Ключові слова: національна балетна вистава, український балет, соцреалізм в балеті, балет, хореографія, танець.

\author{
Klymchuk Iryna \\ National Academy of Management of Culture and Arts
}

\section{UKRAINIAN NATIONAL BALLET PERFORMANCE IN THE USSR IN THE OPTICS OF SOCREALISM}

Summary. The article analyzes the stages of formation of the Ukrainian national ballet performance through the prism of the socialist-realist canon. It is noted that the art analysis of the process of formation of an independent genre of national ballet performance in the optics of social realism is relevant for understanding the process of development of the Ukrainian ballet theater of the Soviet period. It is pointed out that the phenomenon of "national ballet performance" in the USSR was the product of socialist realism, the main postulates of which were classism, party affiliation, nationality and the formula of Soviet art "socialist content, national form." The formation of the phenomenon of "Ukrainian national ballet performance" took place in the context of the requirements for the introduction of socialist realism - the monostyle of the totalitarian state of the USSR. The aesthetics of social realism as a regulator of artistic processes legitimized by the government manifested itself in one of the most powerful tendencies of the 1930's and 1980's. - creation of national ballet performances in the union republics. The postulates of socialist realism in ballet theater could be successfully realized through the synthesis of elements of folk culture, including folk choreography, and the academic aesthetics of ballet theater. Despite ideological guidelines, the creation of Ukrainian ballets had a positive effect on the overall development of the Ukrainian Ballet Theater, expanded its genre range, raised the professional level of artists, organic combination of classical and Ukrainian dance led to a unique lexical system of national ballet performance. The Ukrainian national ballet performance went from the domestic drama "Pan Kanovskyi" by V. Verykivskyi (choreographers V. Lytvynenko and V. Verkhovynets, 1931; the first Ukrainian ballet) through "Lileia" by K. Dankevych (choreographer G. Berezova, 1940; the first Ukrainian choreography ) to the symphonic poem " LIsova pisnia" by M. Skorulskyi (choreographer S. Serhieiev, 1946; V. Vronskyi, 1958), which reflects the main milestones in the development of the ballet theater of the USSR in the 30's and 50's.

Keywords: national ballet performance, Ukrainian ballet, social realism in ballet, ballet, choreography, dance.

Постановка проблеми. Нащіональні україн1 ські балетні вистави (або балети національної тематики, або українські балети тощо) стали своєрідним етномаркерами вітчизняного балетного театру. Становлення џого жанру відбулося в системі соціалістичного реалізму, що був впроваджений як особливий метод радянської культури в 30-х рр. XX ст. Мистецтвознавчий аналіз процесу форормування самостійного жанру національної балетної вистави в оптищі соцреалізму є актуальним для розуміння процесу розвитку українського балетного театру радянського періоду.

Аналіз останніх досліджень і публікацій. До фрундаментальних праць 3 проблем станов- лення нащіональних балетних вистав відносять праці зарубіжних (М. Ельяш [11], Е. Шумілова [10]) та українських (М. Загайкевич [2], Ю. Станішевський [8; 9]) дослідників. Українським національним балетним виставам присвячено дисертації Л. Козинко [3], Л. Маркевич [5], Н. Семенової [7]. Останнім часом з'явились статті Д. Дегтяр [1], А. Король [4], А. Підлипської [6] та ін., що фрокусують увагу на різних аспектах українських національних балетних вистав. Однак жодна праця не присвячена соцреалістичним детермінантам формування нащіональних балетних вистав.

Виділення невирішених раніше частин загальної проблеми. Наукового розроблення

${ }^{1}$ ORCID: https://orcid.org/0000-0002-6253-7626

(C) Климчук I.C., 2020 
потребує вплив соцреалістичного методу на ґенезу української національної балетної вистави.

Мета статті - проаналізувати етапи становлення української національної балетної вистави крізь призму соцреалістичного канону.

Виклад основного матеріалу. Розглядаючи українські національні балетні вистави 20-80-х рр. XX ст. Л. Маркевич констатуе, що «вплив радянської ідеології та абсолютизація принципів соцреалізму обмежували творчу палітру балетмейстерів і артистів балету, однак залучення народної хореографрї на тлі активного розвитку їі національних сценічних форм... мали помітний вплив на фрормування самобутньої стилістики українського балету та його синтетичної художньої мови» [5, с. 5], але не розкриває сутність соцреалістичного впливу на творчий процес. До подібної констатації вдається i Н Семенова («Загальна художня мета українського балету щодо втілення національного менталітету нерідко нівелювалась ідеями соцреалізму за часів існування радянської влади» [7, с. 1]), не надаючи підтвердження.

В цілому ж, френомен «національної балетної вистави» в СРСР став породження соціалістичного реалізму. Національна політика СРСР була спрямована на формування радянської ідентичності, що передбачала нівелювання національної різниці між народами республік, що входили до складу Радянського Союзу. Попри явну спрямованість державної політики на деактуалізацію справжнього етнічного, культивувалися національні ознаки у мистецтві у дозволених варіантах. Сталінська формула мистецтва «соціалістичний зміст, нащіональна форма», що стала одним 3 постулатів «соціалістичного реалізму» (компоненти - класовість, партійність, народність), знайшла втілення в балетному театрі. Під час кристалізації принципів сощіалістичного реалізму на початку 30-х pp. XX ст. в СРСР почав фpopмуватися жанр «національної балетної вистави». В УРСР створення специфічної образної системи національної балетної вистави було одним 3 найвдаліших в країні, попри ідеологічні впливи стало справжнім мистецьким досягненням.

Національна своєрідність мистецтва фрормується у процесі розвитку культури того чи іншого народу, пов'язана зі стійкою історичною спільністю мови, території, економічного життя, психічного складу людей. Головним критерієм національної своерідності мистецтва є вираження митцем загальних рис і властивостей національного характеру, яскравого національного колориту, незалежно від тематичної та структурної специфіки художнього твору [10, с. 11-12].

Національне має прояв у тематиці та проблематиці творчості, у впливі на мистецтво клімату та географічного середовища, характеру та поведінки людей того чи іншого народу, а також у художній мові, тобто проявляеться як у змісті, так і у формі художніх творів.

Національне найбільше проявляеться у виставах, створених на основі національного епосу, народних казок чи легенд. Часто у перших виставах без обробок цитувалися фрольклорні танцювальні джерела. Напрям руху балетного театру в опануванні національних тем можна досить умовно кваліфікувати як еволюційне - від захоплення зовнішніми колоритними ознаками національ- них традищій (достовірність побутових прикмет у звичаях, ритуалах, костюмах, предметах побуту та ін.) до осягнення специфріки національного характеру світосприйняття, прагнення передати його особливості в тематиці та образах [10, с. 19].

Одним 3 найбільш прийнятних визначень національної балетної вистави вважаємо наступне, сформульоване А. Король, - «це балетна вистава, насичена елементами національної ідентифікації (світогляд, етичні, естетичні, психологічні особливості тощо); партитура 3 елементи народного мелосу; хореографія побудована на поєднанні/синтезі класичного танцю й українського танцювального фольклору» [4, с. 152].

У другій половині 30-х років XX ст. у більшості республік СРСР виникли перші національні балети, тісно пов'язані 3 народною художньою образністю, з народною культурою в цілому. У них застосовувались образно-виражальні прийоми, запозичені в чистому, обробленому чи трансформованому вигляді з фольклорних джерел. Ця тенденція була детермінована чіткими соцреалістичними настановами, зокрема, щодо «національної мови» мистецтва, до якої можемо віднести образно-лексичні складові народної хореографії.

Балет «Пан Каньовський» В. Вериківського (б-ри В. Литвиненко та В. Верховинець, прем'єра 1931 р. у Киеві), народна героїчна драма, створений у річищі естетичних тенденцій часу, зокрема, втілення національної теми у театрах республік СРСР. Цей балет вважають першим балетом української тематики на українській радянській сцені, де панували побутові хореографічні та сценографрічні фороми.

Сценічно-пластичне вирішення «Пана Каньовського» не відзначалося стильовою і драматургічною цілісністю. Впровадження народних танцювальних мотивів нагадувало більше аплікацію, ніж органічне втілення у хореографічну тканину. Поряд 3 яскравими поетичними танщювальними сценами зустрічалися розгорнуті пантомімні епізоди, не позбавлені й елементів натуралізму.

За висловом Ю. Станішевського, «у спектаклі утверджувались два основні виражальні засоби класичний танець і національний хореографрічний фольклор, які були основою образно-танцювальної мови українського балету» [9, с. 82]. Однак ці виражальні засоби ще не стали синтезованою мовою українського балету, адже у процесі роботи над виставою між постановниками виникали творчі суперечки: В. Литвиненко був прибічником театралізації фрольклору, а В. Верховинець - копіювання і перенесення фольклору у незмінному вигляді, що суперечило природі балетного театру.

У стилі тогочасного балетного дискурсу Ю. Станішевський зазначає, що «Пан Каньовський» «продовжив кращі реалістичні досягнення героїчних балетів» [9, с. 81].

26 серпня 1940 р. в Киеві вперше показана національна хореодрама - балет «Лілея» за мотивами поезій Т. Шевченка (сценарій В. Чаговець, композитор К. Данькевич, балетмейстер Г. Березова). Весь пафос соцреалістичних орієнтирів балетного театру відбиває Ю. Станішевський, характеризуючи історико-культурний контекст створення вистави: «Героїко-романтична "Лілея" створювалася на київській сцені в той історично важливий для всього багатонаціонального 
радянського балету час, коли ідейно-художні принципи мистецтва соціалістичного реалізму широко утверджувалися в балетмейстерській і акторській творчості» [8, с. 95].

Але не можна применшувати сутність мистецьких досягнень творців балету, в якому спостерігалося органічне злиття класичного і народного танців - важливий крок на шляху створення своерідної лексики української балетної вистави. У балеті відбулося взаємопроникнення двох лексичних систем, а не лише суто технічне офрарблення мови класичного балету елементами українського танцю з метою надання національного колориту. М. Загайкевич вважає, що процес переосмислення фольклорних джерел, що визрів у балетному театрі середини ХХ століття, «позначився на стиранні граней між класичним і характерним танцем, призвів до використання виражальних засобів фольклору як компонента образного вислову. Можна говорити про створення оригінальної хореографрічної мови, що за сутністю є органічним поєднанням класичного та народного танцю, що зазнав переосмислення. I цей процес слід розглядати окремо від так званого процесу збагачення лексики класичного танцю, що відбувався за рахунок пантоміми, акробатичних елементів i, у тому числі, елементів народного танцю» [2, с. 54].

Після Другої світової війни в УРСР поставлені балети, що більшою чи меншою мірою наслідували та розвивали принципи, закладені постановниками «Лілеї» (а, згодом, і «Лісової пісні») щодо цілісності системи української національної балетної вистави: "Маруся Богуславка» А. Свєчникова (б-р С. Сергеєв, 1951), «Хустка Довбуша» А. Кос-Анатольського (б-р М. Трегубов, Львів, 1951), «Сойчине крило» А. Кос-Анатольського (б-р М. Трегубов, Львів, 1956), «Тіні забутих предків» В. Кирейка (б-р Н. Скорульська, Київ, 1963), «Оксана» В. Гомоляки (б-р Р. Клявін, Донецьк, 1964), «Відьма» В. Кирейка (б-р А. Шекеро, Львів, 1967), «Ольга» Є. Станковича (б-р А. Шекеро, Київ, 1982) та ін. На жаль, більшість з цих балетів не зазнала тривалого сценічного життя.
Серед вистав цього періоду найяскравішою $є$ психологічна драма «Лісова пісня» М. Скорульського за драмою-фреєрією Л. Українки (б-р С. Сеггєев, Київ, 1946 р.). У 1958 р. В. Вронський зробив нову сценічну редакцію, в якій більш вдало реалізовано драматургічні особливості твору. Вистава В. Вронського відповідала тенденціям поетизації та симфронізації (принципи танцювальної поліфронії, багатоголосся, розгорнутого ансамблевого акомпанементу і контрапункту солістів і кордебалету) хореографічної мови. Вистава орієнтувалася на музичну драматургію, поставлена синтезованою лексикою класичного й українського народного танцю, цілком вписувалася в соцреалістичні вимоги.

Висновки. Становлення френомену «української національної балетної вистави» відбувалося у контексті вимог щодо впровадження соціалістичного реалізму - моностилю тоталітарної держави СРСР. Естетика соцреалізму як легітимізований владою регулятор мистецьких процесів проявився в одній 3 найпотужніших тенденщій 30-80-х pp. XX ст. - створенні нащіональних балетних вистав в союзних республіках. Постулати соцреалізму, зокрема народність, вимоги "соціалістичного змісту» та «національної форми» у балетному театрі вдало можна було реалізувати саме через синтезування елементів народної культури, зокрема народної хореограdpiï, та академічної естетики балетного театру.

Попри ідеологічні настанови, створення українських балетів позитивно позначилося на загальному розвитку балетного театру України, розширило його жанровий діапазон, сприяло підвищенню професійного рівня митців, органічне поєднання класичного та українського танцю призвело до появи унікальної лексичної системи національної балетної вистави. Українська національна балетна вистава пройшла шлях від побутової драми «Пан Каньовський» (перший український балет) через «Лілею» (перша українська хореодрама) до симфонічної поеми «Лісова пісня», що відбиває основні віхи розвитку балетного театру УРСР у 30-50-х pp.

\section{Список літератури:}

1. Дегтяр Д. Ознаки національного у балеті Галини Березової «Лілея». Вісник Львівського університету. Серія мистецтвознавство. 2014. Вип. 15. С. 182-186.

2. Загайкевич М.П. Драматургія балету. Київ : Наукова думка, 1978. 258 с.

3. Козинко Л.Л. Традиції фольклорної культури в сучасному народно-сценічному танці та балетному театрі України : автореф. дис. ... канд. мистецтвознавства : спец. 17.00.02 «Театральне мистецтво». Київ, 2012.18 с.

4. Король А. Українські балети як етномаркери. Танцювальні студї. 2019. Т. 2. № 2. С. $149-157$.

5. Маркевич Л. Трансформація системи художньої мови української національної балетної вистави в 20-80 роках XX ст. : авторефр. дис. ... канд. мистецтвознавства : спец. 26.00.01 «Теорія та історія культури». Івано-Франківськ, 2019. 23 с.

6. Підлипська А. Особливості прояву «національного» в хореографічному мистецтві. Соціальні колунікацї : матеріали Всеукр. наук. конфб. "Соціальні колунікаціӥ: стан, проблели, тенденцї̈, Київ, 26-27 квітня 2012 р. Київ : Видавн. центр КНУКіМ, 2012. С. 147-149.

7. Семенова Н.M. Національна балетна вистава в українській хореографічній культурі XX - початку XXI століть : авторефр. дис. ... канд. мистецтвознавства : спец. 26.00.04 «Українська культура». Харків, 2019. 16 с.

8. Станішевський Ю. Балетний театр Радянської України: 1925-1985 : Шляхи і проблеми розвитку. Київ : Музична Україна, 1986. 235 с.

9. Станішевський Ю. Балетний театр України: 225 років історії. Київ : Музична Україна, 2003. 438 с.

10. Шумилова Э.И. Национальное своеобразие балета. Москва : Знание, 1976. 48 с.

11. Эльяш Н. Балет народов СССР. Москва : Знание, 1977. 167 с.

\section{References:}

1. Dehtiar D. (2014). Oznaky natsionalnoho u baleti Halyny Berezovoi «Lileia» [Signs of the national ballet in Galina Berezova's ballet "Lileia"]. Bulletin of Lviv University. Art history series, vol. 15, pp. 182-186. 
2. Zahaikevych M.P. (1978). Dramaturhiia baletu [Ballet drama]. Kyiv: Naukova dumka. (in Ukrainian)

3. Kozynko L.L. (2012). Tradytsii folklornoi kultury v suchasnomu narodno-stsenichnomu tantsi ta baletnomu teatri Ukrainy [Traditions of folk culture in modern folk-stage dance and ballet theater of Ukraine] (PhD Thesis), Kyiv.

4. Korol A. (2019). Ukrainski balety yak etnomarkery [Ukrainian ballets as ethnomarkers.]. Dance studies, vol. 2, no. 2 , pp. $149-157$.

5. Markevych L. (2019). Transformatsiia systemy khudozhnoi movy ukrainskoi natsionalnoi baletnoi vystavy $v$ 20-80 rokakh XX st. [Transformation of the system of artistic language of the Ukrainian national ballet performance in the 20-80s of the XX century] (PhD Thesis), Ivano-Frankivsk.

6. Pidlypska A. (2012). Osoblyvosti proiavu «natsionalnoho» v khoreohraafichnomu mystetstvi [Features of the manifestation of "national" in the art of choreography]. Sotsialni komunikatsii: materialy Vseukr. nauk. konf. "Sotsialni komunikatsii: stan, problemy, tendentsii», Kyiv, 26-27 kvitnia 2012 r. Kyiv: Vydavn. tsentr KNUKiM, pp. 147-149.

7. Semenova N.M. (2019). Natsionalna baletna vystava v ukrainskii khoreohrafichnii kulturi XX - pochatku XXI stolit [National ballet performance in the Ukrainian choreographic culture of the XX - early XXI centuries] (PhD Thesis), Kharkiv.

8. Stanishevskyi Yu. (1986). Baletnyi teatr Radianskoi Ukrainy: 1925-1985: Shliakhy i problemy rozvytku [Ballet Theater of Soviet Ukraine: 1925-1985: Ways and Problems of Development]. Kyiv: Muzychna Ukraina. (in Ukrainian)

9. Stanishevskyi Yu. (2003). Baletnyi teatr Ukrainy: 225 rokiv istorii [Ballet Theater of Ukraine: 225 years of history]. Kyiv: Muzychna Ukraina. (in Ukrainian)

10. Shumilova E.I. (1976). Natsionalnoe svoeobrazie baleta [National identity of ballet]. Moscow: Znanie. (in Russian)

11. El'yash N. (1977). Balet narodov SSSR [Ballet of the peoples of the USSR]. Moskva: Znanie. (in Russian) 